\title{
Kontribusi Pelatihan Berkisah Tema Keislaman Kepada Kompetensi Guru dan Siswa Taman Kanak-Kanak
}

\author{
Bahril Hidayat, Dian Tri Utami \\ Universitas Islam Riau, Indonesia \\ Jl. Kaharuddin Nasution No. 113, Perhentian Marpoyan, Kota Pekanbaru, Indonesia. \\ Email: bahrilhidayat@fis.uir.ac.id
}

\begin{abstract}
The quality and professionalism of Kindergarten or Raudhatul Athfal (RA) teachers will determine early childhood development. The teacher should have the creativity and arts teaching as a part of expertise in learning process. Expected learning result in accordance with the characteristics of early childhood, namely learning through play or play while learning. Storytelling is one of those included in play activities. This article contains the results of descriptive qualitative research with 5 respondents which describing that storytelling techniques increase teacher's competencies in learning process. Another competencies obtained by teachers after participating in storytelling training are the improvement of Moral Competencies and the sensitivity to understanding the Early Childhood Development, specifically the Development of Children's Languages. In addition, the results of the study increasingly Islamic Competencies of teachers and students by means of teachers raising or choosing true stories of prophets and apostles in providing storytelling techniques onto early childhood students.
\end{abstract}

Keywords: Story-telling, Teacher Competencies, Islamic Early Childhood Education

\begin{abstract}
Abstrak: Kualitas guru Taman Kanak-Kanak (TK) atau Raudhatul Athfal (RA) yang profesional akan menentukan perkembangan anak usia dini. Guru juga harus memiliki kreativitas dan seni yang mendidik sebagai bentuk keahlian dalam mengajar. Belajar yang diharapkan sesuai dengan karakteristik anak usia dini, yaitu belajar melalui bermain atau bermain sambil belajar. Bercerita merupakan salah satu yang termasuk ke dalam kegiatan bermain. Artikel ini berisikan hasil penelitian jenis penelitian kualitatif deskriptif dengan 5 orang responden yang mengungkapkan bahwa teknik berkisah meningkatkan kompetensi guru dalam mengajar. Peningkatan kompetensi khusus lainnya yang diperoleh guru setelah mengikuti pelatihan teknik berkisah adalah peningkatan kompetensi moral dan semakin peka untuk memahami tahap perkembangan anak, khususnya perkembangan bahasa anak. Selain itu, hasil penelitian menunjukkan adanya peningkatan Kompetensi Keislaman pada guru dan anak didik dengan cara guru mengangkat atau memilih kisah-kisah nyata nabi dan rasul dalam memberikan teknik berkisah kepada siswa atau peserta didik anak usia dini.
\end{abstract}

Kata Kunci: Teknik Berkisah, Kompetensi Guru, Pendidikan Islam Anak Usia Dini 


\section{PENDAHULUAN}

Guru seharusnya menguasai dan menerapkan pengetahuan dan kemampuan mendidik yang mereka miliki. Pengetahuan yang mendalam yang berkaitan dengan bidang masing-masing. Selain itu, guru juga membutuhkan pengetahuan lain yang berhubungan dengan keprofesiannya agar dalam pembelajaran sesuai dengan standar kompetensi guru. Penguasaan guru terhadap bidang keprofesiannya tersebut diharapkan diharapkan mampu melahirkan peserta didik yang baik, bermoral, berkarakter, dan berkualitas dalam bidang pengetahuan sejak usia dini melalui bermain sambil belajar.

Guru juga harus memiliki potensi kreativitas dan potensi seni. Potensi seni dan kreativitas dari guru diharapan mampu melakukan pendidikan dan membentuk pemahaman konsep tumbuh kembang anak berdasarkan keahlian mengajar yang guru miliki. Pencapaian kompetensi tersebut guru perlu membina dan melatih diri secara baik karena fungsi guru adalah membina dan mengembangkan kemampuan peserta didik secara profesional di dalam proses belajar mengajar. Belajar yang diharapkan sesuai dengan karakteristik anak usia dini, yaitu belajar melalui bermain atau bermain sambal belajar. Bercerita merupakan salah satu yang termasuk ke dalam kegiatan bermain.

Bercerita atau Teknik Mendongeng juga dikenal dengan istilah Teknik Berkisah dalam dimensi akademis dan praksis di lingkup pendidikan anak usia dini. Teknik Berkisah dilaksanakan dalam upaya memperkenalkan, memberikan keterangan, atau penjelasan tentang hal baru untuk menyampaikan pembelajaran. Kegiatan bercerita tidak sekadar bersifat hiburan dan bermain saja, akan tetapi memiliki tujuan lain yang penting, yaitu mengenalkan lingkungan alam, budi pekerti, dan mendorong anak berprilaku positif.

Latif (2012) mengemukakan bercerita adalah bertutur dengan intonasi yang jelas, menceritakan sesuatu hal yang berkesan, menarik, memiliki nilai-nilai khusus dan tujuan khusus. Di sisi lain, teknik bercerita atau berkisah bertujuan agar anak mampu mendengar apa yang disampaikan oleh orang lain dan dapat bertanya apabila tidak memahaminya. Hal ini sesuai dengan yang diungkapkan Sonawat dan Francis (2007) bahwa story telling is an activity that helps the chid to listen and have an experiences in speaking while talking about the story or telling tehe original stories.

Bercerita merupakan suatu aktivitas yang membantu anak untuk mendengar serta memiliki pengalaman berbicara ketika mereka bercerita tentang suatu cerita atau menceritakan sesuatu yang mereka alami (cerita asli). Hal ini menunjukkan bahwa bercerita memperoleh pelepasan emosional melalui pengalaman fiktif atau imajinatif yang belum pernah mereka alami di kehidupan nyata dan memberikan pengalaman belajar untuk berlatih mendengarkan dan mengembangkan kemampuan kognitif.

Berkaitan dengan hal itu, Moeslichatoen (2004) mengemukakan bahwa kegiatan bercerita merupakan salah satu pemberian pengalaman belajar kepada anak dengan membawakan cerita secara lisan. Cerita yang dibawakan guru harus menarik, improvisasi yang ditunjukkan guru sebaiknya mendekati kisah nyatanya agar mengundang perhatian anak serta tidak lepas dari tujuan pendidikan bagi anak. Isi cerita itu disesuaikan dengan kebutuhan anak, maka anak akan dengan mudah memahami isi cerita itu, anak akan mendengarkan dengan penuh perhatian dan akan mudah dapat menangkap isi cerita. 
Menurut Andi Yudha (2007) ketika bercerita atau mendengarkan cerita, anak belajar berbicara dalam gaya yang menyenangkan serta menambah perbendahaaran kata dan bahasanya. Hal ini dapat dikatakan bahwa cerita bias membuat anak menjadi kreatif, kaya imajinasi serta memiliki banyak kosa kata. Pada dasarnya bercerita adalah kegiatan berbagi rasa, membuka diri secara tulus, mengungkapkan nilai-nilai luhur, dan menyampaikan pengalaman dengan sungguh-sungguh sehingga dapat diterima dan diserap oleh anak-anak.

Berdasarkan pemaparan di atas maka dapat dideskripsikan bahwa kegiatan bercerita adalah suatu aktivias lisan untuk memberikan pengalaman, pesan, pendidikan moral kepada anak agar anak dapat mengembangkan daya imajinasi dan mengasah kreativitas serta dapat mengasah aspek-aspek perkembangan seperti bahasa seperti membaca dan berbicara. Dalam usaha membangun manusia Indonesia seutuhnya maka para guru merupakan perangkat pelaksana yang terdepan.

Para guru sebagai perangkat pelaksana pendidikan membutuhkan persyaratan atau kriteria tertentu agar mampu melaksanakan tugas kependidikan, yaitu guru sebagai profesi yang mulia merupakan perpaduan panggilan hati, teknologi, pengetahuan, ilmu, dan seni. Semua aspek tersebut bertumpu kepada landasan pengabdian yang utuh disertai penanaman sikap dan kepribadian mulia berlandasakan konsep moral, agama, dan keislaman.

Sementara itu, pada kenyataannya di lembaga pendidikan ditemukan sebagian guru yang belum memenuhi standar kompetensi sebagaimana diharapkan. Pertama, guru belum memiliki pengetahuan dan keterampilan mengemas strategi bercerita atau berkisah kepada peserta didik. Misalnya, banyak guru yang hanya bercerita seperti hanya membacakan buku cerita tanpa menggunakan teknik dan tanpa mengutamakan nilai yang terkandung dalam cerita. Kedua, kepribadian dan emosi guru masih labil. Misalnya, guru tidak mampu membedakan masalah pribadi dengan tanggung jawab di sekolah. Ketiga, kemampuan guru menguasai materi pembelajaran dan mengelola kelas (peserta didik) masih lemah (dangkal). Misalnya, guru kesulitan dalam mengaplikasikan materi yang diajarkan dan mengelola peserta didik yang unik dengan kepribadian yang bervariasi.

Kualitas guru Taman Kanak-Kanak (TK) atau Raudhatul Athfal (RA) yang profesional merupakan salah satu factor penentu perkembangan atau tumbuh kembang anak usia dini sebagai peserta didik. Perkembangan mereka perlu ditangani oleh pendidik yang profesional. Pendidik TK/RA berbeda dengan pendidik SD ataupun SMP. Pendidik TK/RA bukan sekadar mengajar, namun pendidik atau guru TK/RA seharusnya memahami fase perkembangan anak usia dini yang ada pada setiap individu anak usia dini. Hal itu dibutuhkan karena masa anak usia dini memiliki kepekaan tumbuh kembang yang sensitif untuk meningkatkan potensi mereka yang unik.

Pendidikan yang berkualitas akan menghasilkan tokoh atau sosok guru (pendidik) yang memiliki empat kompetensi dasar, yaitu kompetensi pedagogis (pedagogik), profesional, sosial, dan kepribadian. Kompetensi pedagogis pada guru berkaitan dengan penguasaan pendidik terhadap materi yang diajarkan, kompetensi kepribadian menuntut standar pendidik yang mempunyai kepribadian yang baik. Sementara itu, kompetensi profesional berhubungan kemampuan menyelesaikan tugas keguruan dan kependidikan, dan kompetensi sosial berhubungan dengan aspek-aspek yang terjadi di dalam interaksi yang baik dengan peserta didik.

Dengan empat kompetensi di atas, diharapkan pelatihan berkisah mampu untuk menumbuhkan dan mengembangkan kompetensi pendidik tersebut. Pelatihan berkisah merupakan 
gerakan membangun karakter bangsa melalui cerita yang diusung berbagai komunitas pengkisah di Indonesia. Komunitas maupun lembaga pendidikan yang diusung itu merupakan mata rantai perjuangan dunia dakwah dan tarbiyah untuk pembentukan karakter dan kepribadian di kalangan anak-anak.

Melalui pelatihan berkisah guru mendapatkan kompetensi pedagogis, yaitu menguasai materi pembelajaran yang disampaikan melalui berkisah kepada anak. Kompetensi kepribadian dapat direalisasikan dengan kisah-kisah Islami yang bermakna guru memiliki nilai akhlak, mengidentifikasi perilaku diri, dan anak. Kompetensi profesional, yaitu guru dapat termotivasi untuk belajar dan berlatih teknik berkisah, membangun tekad untuk terus maju (kreasi dan inovatif) serta mengevaluasi daya serap anak. Kompetensi sosial guru dengan memilih kata-kata yang memuliakan saat berinteraksi dengan anak maupun melibatkan anak melaui tanya jawab.

Berkaitan dengan pemaparan di atas, perlu dilakukan kajian dan penelitian tentang peningkatan motivasi mendongeng pada guru anak usia dini melalui pelatihan teknik berkisah. Dengan mengungkap peningkatan motivasi dan aspek-aspek lain yang berkaitan dengan kompetensi guru anak usia dini melalui pelatihan teknik berkisah akan meningkatkan capaian pembelajaran pada anak usia dini sebagai peserta didik.

Berbagai penelitian sudah dilakukan berkaitan dengan pengaruh teknik berkisah (bercerita; storytelling). Salah satu penelitian yang berjudul Bercerita Sebagai Metode Mengajar Bagi Guru Raudlatul Athfal Dalam Mengembangkan Kemampuan Dasar Bahasa Anak Usia Dini di Desa Ngembalrejo Bae, Kudus (Amalia, T.Z., 2015). Penelitian tersebut menyimpulkan bahwa secara umum para peserta menyatakan ketertarikannya dengan metode bercerita karena metode ini dapat memperkaya kemampuan pedagogik para pendidik dalam menyampaikan materi pembelajaran anak-anak usia dini. Selain itu, banyak responden guru yang menyatakan bahwa pengalaman berkisah adalah pengalaman pertama mereka mengikuti pelatihan metode bercerita. Oleh karena itu, banyak hal dapat mereka ambil dalam pelatihan ini, baik pengalaman yang berhubungan dengan materi cerita maupun teknikteknik dalam metode bercerita. Hampir keseluruhan pendidik mengharapkan pelaksanaan metode bercerita berjalan baik.

Selain itu, Fitroh, Siti Fadjryana, and Evi Dwi Novita Sari (2015) pernah meneliti Dongeng sebagai media penanaman karakter pada anak usia dini. Hasil penelitian menunjukkan dongeng sebagai media dalam penanaman karakter sangatlah efektif untuk diterapkan kepada anak usia dini dan perlunya pembiasaan serta contoh yang baik untuk menumbuhkan karakter dari anak.

Berdasarkan uraian di atas, penelitian ini berupaya untuk mengungkap dampak atau peningkatan kompetensi guru TK/RA melalui pelatihan berkisah. Data awal diambil kepada peserta pelatihan melalui kuesioner terbuka yang dibagikan kepada 70 peserta pelatihan. Dengan adanya data awal tersebut, peneliti akan mengungkap dan mendeskripsikan

kompetensi guru TK/RA melalui penelitian ini.

\section{METODE PENELITIAN}

Jenis penelitian dalam riset ini adalah penelitian kualitatif deskriptif, yaitu data yang dikumpulkan berbentuk kata-kata, gambar, bukan angka-angka. Menurut Bogdan dan Taylor, sebagaimana yang dikutip oleh Moleong, L.J. (2000), penelitian kualitatif merupakan prosedur penelitian yang menghasilkan data deskriptif berupa kata-kata tertulis atau lisan dari orang-orang dan perilaku yang diamati. Di sisi lain, penelitian deskriptif merupakan suatu bentuk penelitian yang ditujukan untuk mendeskripsikan atau menggambarkan fenomena-fenomena 
yang ada, baik fenomena alamiah maupun rekayasa manusia.

Tujuan dari penelitian deskriptif untuk membuat pendeskripsian (pemaparan) secara sistematis, faktual, dan akurat mengenai fakta dan sifat populasi atau daerah tertentu yang diteliti, dalam hal ini guru perempuan anak usia dini yang sudah mendapatkan pelatihan berkisah yang diharapkan mengembangkan kompetensi mereka sebagai guru. Penelitian ini menggunakan teknik pengumpulan data sebagai berikut.

\section{Wawancara}

Peneliti melakukan Wawancara langsung terhadap subjek penelitian dengan menggunakan draft wawaancara yang telah disusun sebelumnya berdasarkan kriteria-kriteria pribadi yang matang. Esensi dari draft Wawancara itu adalah untuk mengungkap ada tidaknya peningkatan kompetensi guru melalui pelatihan berkisah pada subjek penelitian. Peneliti juga meWawancarai key person sebagai data pembanding ataupun data tambahan untuk penelitian ini.

\section{Studi Literatur}

Prosedur pengumpulan data studi literatur adalah melalui pembahasan kepustakaan tentang peningkatan kompetensi guru melalui pelatihan berkisah mendongeng dan kompetensi psikologis lainnya pada subjek penelitian. Pembahasan kepustakaan ini bertolak dari analisis pustaka (referensi) ilmiah dan dibahas dengan jawaban subjek penelitian pada sub bab Hasil Penelitian. Peneliti berupaya mengkaitkan dan menghubungkan aspek-aspek penelitian yang ingin diukur melalui pembahasan kepustakaan. Dengan demikian peneliti dapat menjabarkan proses pengolahan data secara luas dan representatif.

Metode Analisis Data dilakukan secara kualitatif. Analisis data tersebut terdiri beberapa tahapan (Miles \& Huberman, 1992).

Pertama, Pengumpulan data. Data dikumpulkan dari hasil Wawancara dan observasi. Hasilnya ditulis dalam bentuk catatan lapangan dan dalam bentuk paparan (deskriptif). Data tersebut kemudian disalin ke dalam bentuk transkrip.

Kedua, Mereduksi data dengan pembuatan koding dan kategorisasi. Peneliti membuat kategorisasi tematis berdasarkan topik peneliti yang diterapkan pada jawaban naratif subjek penelitian.

Ketiga, Menyajikan data dalam bentuk teks naratif.

Keempat, Mencari triangulasi data melalui pembandingan kategori-kategori yang ditemukan Wawancara, observasi, kuesioner terbuka, dan studi pustaka sehingga ditemukan kategori yang mewakili metode-metode tersebut.

Kelima, Menyimpulkan, yaitu melakukan penarikan kesimpulan melalui deskripsi naratif.

Sementara itu, subjek penelitian dalam penelitian ini lima orang guru TK/ RA di kota Pekanbaru yang diambil dari tujuh puluh peserta pelatihan teknik berkisah yang dilaksanakan 1-2 Agustus 2017, di Fakultas Agama Islam, Universitas Islam Riau. Subjek memberikan informasi atau data penelitian melalui Wawancara untuk melengkapi data yang diperoleh saat penelitian. Sebelumnya semua peserta pelatihan sudah diberikan kuesioner terbuka pada sesi terakhir pelatihan teknik berkisah.

\section{HASIL DAN PEMBAHASAN}

Wawancara dilaksanakan dengan menggunakan teknik purposive sampling terhadap 5 orang narasumber (responden atau subjek penelitian) yang dilakukan di 2 Taman Kanak-kanak (TK) dan 3 Raudhatul Athfal (RA), 1 orang guru masing-masing lembaga. Narasumber atau subjek penelitian yang berhasil diWawancarai secara intensif dengan nama menggunakan inisial, yaitu subjek: A, B, C, D, dan E.

Untuk memperkuat substansi data hasil Wawancara yang dilaksanakan 
peneliti dan observasi maka teknik lain dengan cara melakukan penelusuran terhadap dokumen dan arsip proses belajar mengajar yang ada pada subjek penelitian. Data hasil penelitian ini diuraikan sebagai berikut.

\section{Meningkatkan Kompetensi Sosial}

$\begin{array}{ccc}\text { Peneliti } & \text { melakukan teknik } \\ \text { Wawancara dan dokumentasi untuk } & \end{array}$ setalah mengikuti pelatihan berkisah. Menurut $C$ pelatihan berkisah sangat membantu dalam menyampaikan cerita agar cerita dapat lebih menarik dan membuat anak senang. Narasumber mengatakan bahwa:

"Saya sangat senang dengan adanya pelatihan berkisah ini karena sangat membantu saya dalam menyampaikan cerita agar disampaikan lebih menarik dan anak-anak senang menyimak ceritanya." (Wawancara subjek C. 25 September 2017).

Narasumber D menanggapi pelatihan berkisah penting sekali untut anak usia dini. Narasumber D mengatakan bahwa:

"Mengikuti peltihan berkisah menurut saya penting sekali untuk anak usia dini, membantu perkembangan berbicara dan menyimak anak." (Wawancara Subjek D, 28 September 2017).

\section{Meningkatkan Kompetensi Profesional dan Moral}

Selanjutnya narasumber A diWawancarai dan mendapatkan jawaban bahwa pelatihan berkisah membuat banyak ilmu, wawasan, dan nilai moral diperoleh guru dan sangat tepat untuk dipalikasikan kepada peserta didik. Subjek mengatakan:

"Menurut saya setelah mengikuti pelatihan berkisah, saya merasa banyak ilmu yang didapat yang cocok dan sangat tepat apabila diimplementasikan oleh pendidik kepada peserta didik. Karena pendidik dapat menanamkan nilai moral dan agama tanpa peserta didik merasa digurui, kisahkisah yang disampaikan pendidik akan masuk ke alam bawah sadar peserta didik, tidak hanya aspek moral dan agama saja, kelima aspekyang penting dikembangkan pada anak usia dini pun akan tersampaikan dan terasah melalui berkisah." (Wawancara Subjek A, 2 oktober 2017).

Narasumber B menjawab pertanyaan Wawancara yaitu dapat dengan mudah mengaplikasikan berkisah kepada anak-anak.

"Setelah saya mengikuti pelatihan berkisah, saya sendiri merasa dapat mengaplikasikan cara ini dengan tidak monoton. Tidak hanya duduk diam dan hanya bercerita/ berkisah kepada anakanak namun bisa dilakukan dengan berbagai cara." (Wawancara subjek B, 6 oktober 2017).

\section{Meningkatkan Kompetensi Keislaman Guru dan Peserta Didik}

Subjek C mengatakan perencanaan pembelajaran dilakukan dengan cara berkisah atau bercerita dengan mengangkat kisah-kisah nyata nabi dan rasul dalam pembelajaran untuk meningkatkan kompetensi keislaman guru dan peserta didik melalui tema kisah Nabi dan Rasul. Narasumber mengatakan bahwa:

"Saya mempersiapkan kegiatan belajar dalam implementasi teknik berkisah melalui kegiatan inti anak didik pada proses perencanaan adalah dengan mengangkat kisah-kisah nyata nabi dan rasul dalam skenario kegiatan inti yaitu pada saat kegiatan dalam area bahasa sehingga diharapkan bisa meningkatkan nilai keislaman pada anak-anak didik saya." (Wawancara subjek C,. 25 September 2017).

Sejalan dengan jawaban subjek C subjek penelitian D mengungkapkan tahap perencanaan dilaksanakan dengan mengangkat kisah nabi dan rasul pada kegiatan inti dengan menambahkan lagi anggota pengkisah, misalnya dua orang guru sebagai pembeda tokoh dan suara. Narasumber D menyatakan:

"saya mencantumkan muatan-muatan kisah-kisah nyata nabi dan rasul dengan dibawakan oleh dua orang pengkisah yakni 
dua orang guru sebagai bentuk pembeda tokoh dan suara. Perencanaan disiapkan pada kegiatan inti dan juga dipersiapkan ketika jam pulang." (Wawancara subjek D, 28 September 2017)

Sedangkan narasumber atau subjek A menyatakan lebih memasukkan nilainilai sifat dan karakter manusia yang islami seperti saling membantu, berbagai, simpati dan empati terhadap orang lain. Subjek memaparkan:

"Pada perencanaan ya menyiapkan cerita dan alat yang akan digunakan serta memasukkan nilai-nilai sifat keislaman manusia pada sebuah cerita yang akan disampaikan. Karena sebenarnya berkisah menurut saya adalah bagaiman membentuk karakter atau akhlak seorang anak". (Wawancara subjek A, 2 Oktober 2017)

Berbeda dengan subjek B yang belum begitu menerapkan teknik berkisah di sekolah atau lembaganya. Meskipun demikian, subjek penelitian atau narasumber B mengungkapkan untuk perencanaan subjek B juga memasukkan teknik berkisah ke dalam RKH dan RKM. Narasumber B menyatakan:

"Saya hanya menyiapkan pembelajaran seperti biasanya hanya saja ada penambahan teknik berkisah ini dalam rencana kegiatan pembelajaran, misalnya pada hari jumat setelah anak praktek shalat". (Subjek B, 6 oktober 2017).

Berdasarkan hasil dokumentasi RKH dan RKM menunjukkan bahwa ada bagian yang menuliskan teknik berkisah agar diimplementasikan di dalam kegiatan belajar mengajar. Pada bagian teknik berkisah yang dikembangkan ditulis dibagian kolom kompetensi dasar siswa yang diharapkan sebagai bentuk kesesuaian perencanaan dan pelaksanaan proses belajar mengajar. Isi yang dibuat dengan mengangkat cerita atau kisah nyata nabi dan rasul serta karakter atau sifat keislaman manusia.

\section{Teknik Berkisah Membantu Memahami Perkembangan anak}

Menurut subjek C dengan teknik berkisah mempermudah guru untuk menilai aspek perkembangan anak. Narasumber C mengatakan:

"Langkah-langkah guru dalam melaksanakan kegiatan pembelajaran meliputi kegiatan awal, kegiatan inti, dan kegiatan penutup. Jadi diselipkan teknik berkisah diantara tiga bagian itu. Jadi ketika berkisah, guru langsung dapat menilai aspek perkembangan anak yang berkembang, contohnya: ada anak yang menyimak dan langsung ingin mengulangi dengan artian bahwa perkembangan bahasa anak berkembang, kemudian ada anak yang menasehati temannya yang berkaitan dengan cerita, dalam artian perkembangan sosial emosional atau perkembangan moral agamanya anak tampak berkembang". (Wawancara Subjek C, 25 september 2017)

Narasumber D menambahkan bahwa teknik berkisah mempunyai dua peranan dalam kegiatan pembelajaran yaitu menanamkan karakter pada anak dan meningkatkan kompetensi guru dalam pembelajaran. Beliau menyatakan: "Saya melihat dengan teknik berkisah terlihat jelas dapat mengembangkan aspek perkembangan anak khususnya kognitif dan bahasa, mampu mengingat dan kembali menceritakan cerita. Selain itu, untuk guru itu sendiri, contohnya saya, saya merasa mendapatkan kompetensi atau kemampuan lain di bidang menampilkan ekspresi, dan khususnya intonasi, hubungan dengan bahasa saya sendiri." (Wawancara Subjek D, 28 september 2017.

Selanjutnya narasumber A mengatakan bahwa:

"Aplikasi berkisah sangat membantu guru mengidentifikasi perkembangan anak. Guru bisa melihat keseharian anak, bagaimana moral dan agama anak, sosial emosional, kognitif anak serta aspek perkembangan bahasa anak. Contohnya saya dapat menilai aspek perkembangan bahasa anak dari cara mengadakan tanya jawab seusai cerita yang disampaikan." (Wawancara Subjek A, 2 Oktober 2017).

Kemudian peneliti kembali

meWawancarai narasumber B. 
Narasumber B berpendapat bahwa teknik berkisah mempermudah menilai aspek perkembangan moral dan agama anak. Narasumber B mengatakan:

"Guru berkisah dengan mengkisahkan cerita-cerita nabi, rasul, dan cerita agama islam agar karakter anak menjadi baik. Melalui lingkungan, alam semesta dan semua yang sudah diberi Allah kepada kita juga menjadi topik yang bisa diceritakan kepada anak-anak. Jadi, teknik berkisah sangat mempermudah saya untuk melakukan penilaian terhadap aspek perkembangan moral dan agama. Kaitannya dengan isi cerita yang disampaikan mengangkat tema tentang nilai-nilai islami yang membentuk karaktek anak atau peserta didik. Anak sangat antusias ketika mendengarkan guru berkisah." (Wawancara Subjek B, 6 oktober 2017).

\section{Peningkatan Kompetensi Kepribadian Guru dan Anak Didik}

Peneliti melakukan teknik

Wawancara dan dokumentasi untuk memperoleh data dari respon guru setelah mengikuti pelatihan berkisah. Menurut subjek C pelatihan berkisah dapat meningkatkan kompetensi guru dalam bidang kompetensi kepribadian. Narasumber C mengatakan:

"Setelah saya mengikuti dan mengimplikasikan teknik berkisah, saya merasa untuk kompetensi saya sendiri berkembang, yaitu dalam kompetensi kepribadian. Saya menjadi lebih mampu untuk menjadi model atau teladan dalam berprilaku sesuai dengan isi kisah-kisah yang saya sampaikan. Dengan cerita yang saya sampaikan, saya terlebih dahulu berpikir dan menyerap fungsi dari kisah tersebut. Misalnya, mengajarkan anak untuk bertutur kata yang benar dan sopan, menumbuhkan percaya diri dengan anak ketika melihat saya berkisah, secara otomatis memancing kepercayaan diri anak untuk maju mengulangi cerita, ketika ada anak atau peserta didik yang berkelahi atau berebutan, saya menunjukkan sikap tidak berat sebelah dan memberikan pemahaman." (Wawancara Subjek C, 25 september 2018).

Peneliti melanjutkan Wawancara ke narasumber D. Didapatkan jawaban yang berbeda dengan narasumber $C$, narasumber D mengatakan:

"Dengan mengikuti pelatihan berkisah dan kemudian mengimplikasikan di lembaga, saya melihat banyak perkembangan yang diperoleh oleh anak atau peserta didik, diantaranya: anak mampu menyimak, mengungkapkan kisah, berbagi dengan teman, empati, simpati, kejujuran. Dengan itu, saya merasa hal ini juga bagus untuk disosialisasikan kepada orang tua sebagai penunjang perkembangan anak di rumah. Mengadakan pertemuan dan melatih orang tua dalam pertemuan tersebut. Memotivasi orang tua atau masyarakat untuk turut andil memperhatikan tumbuh kembang anak. Dengan begitu saya merasa kompetensi sosial saya telah berkembang." (Wawancara Subjek D, 28 september 2017).

Sedangkan narasumber A menyatakan banyak kompetensi yang harus dimiliki oleh guru berkembang di diri saya melalui teknik berkisah ini. Subjek A memaparkan:

"Saya mampu menjadi fasilitator, saya bisa berpikir kritis terhadap pemilihan kisah yang ingin disampaikan, saya menjadi sabar dan tekun dalam melaksanakan kegiatan pembelajaran karena penggunaan teknik yang menarik, saya mampu memberikan informasi kepada teman-teman guru, orang tua, dan masyarakat sekitar berhubungan dengan teknik berkisah. Khususnya, saya berkompeten pada kompetensi profesional, yang mana saya mampu mengelola kelas, mengelola pembelajaran, terampil dalam berkisah, serta baik dalam lingustik." (Wawancara Subjek A, 2 oktober 2017).

Selanjutnya hasil Wawancara dari subjek penelitan B memaparkan:

"Saya menguasai strategi teknik berkisah (mulai dari penokohan, intonasi, improvisasi, serta ekspresi), saya juga mampu menggunakan teknologi sebagai penunjang kualitas kegiatan pembelajaran 
dalam kegiatan teknik berkisah. Selain itu saya merasa mampu untuk menjadi contoh atau model bagi anak atau peserta didik saya dalam kaitannya tentang karakter." (Wawancara subjek B, 6 oktober 2017).

Berdasarkan data penelitian di atas, peneliti menggunakan hasil penelitian lain dalam pembahasan hasil penelitian ini sebagai bentuk pembahasan hasil penelitian. Salah satu penelitian sejenis yang dijadikan pembahasan adalah penelitian Hijriati (2016), hasil penelitian menunjukkan guru memiliki kompetensi yang memadai, yakni kompetensi pedagogis berbentuk kemampuan mempersiapkan perangkat pembelajaran. Kompetensi profesional dalam bentuk mengikuti atau menghadiri kegiatan pelatihan maupun workshop yang dilaksanakan dinas dan lembaga tertentu untuk meningkatkan kemampuan keprofesian. Sementara itu, pembentukan Kompetensi Kepribadian dicapai dengan memberikan suri teladan kepada anak didik, menjaga kode etik pendidik atau guru. Pada aspek kompetensi sosial, guru menjaga hubungan interpersonal yang baik dengan lingkungan sosial, baik orang tua atau wali murid, maupun masyarakat sekitar. Dengan merujuk pada penelitian Hijriyati tersebut, pelatihan berkisah sebagai kegiatan pelatihan dan seminar menunjukkan hasil bahwa kompetensi guru, khususnya pada kompetensi profesional akan meningkat. Jadi, melalui pelatihan berkisah dalam penelitian ini sesuai dengan jawaban subjek penelitian A yang menunjukkan peningkatan Kompetensi Profesional. Lebih jauh lagi, Subjek A menunjukkan peningkatan Kompetensi Moral dalam mengajar setelah mengikuti pelatihan berkisah. Peningkatan Kompetensi Moral tersebut menunjukkan adanya temuan tambahan dalam penelitian ini.

Sementara itu, peningkatan Kompetensi Pedagogis diperoleh dari data Subjek C, yaitu dengan perencanaan pembelajaran dilakukan dengan cara berkisah atau bercerita. Lebih jauh lagi, data penelitian dari subjek C menunjukkan adanya peningkatan Kompetensi Keislaman pada guru dan anak didik dengan cara guru mengangkat atau memilih kisah-kisah nyata nabi dan rasul dalam memberikan teknik berkisah kepada siswa TK. Hal tersebut selaras dengan temuan penelitian Siti Fadjryana Fitroh dan Evi Dwi Novita Sari (2015) yang pernah meneliti Dongeng Sebagai Media Penanaman Karakter Pada Anak Usia Dini. Hasil penelitian menunjukkan dongeng sebagai media dalam penanaman karakter sangatlah efektif untuk diterapkan kepada anak usia dini dan perlunya pembiasaan serta contoh yang baik untuk menumbuhkan karakter dari anak. Penumbuhan karakter pada anak dan guru melalui teknik berkisah juga disampaikan oleh Subjek B dan subjek D, yaitu subjek penelitian merasakan kompetensi karakter dan kepribadian mereka berkembang, yaitu dalam kompetensi Kepribadian. Subjek menjadi lebih mampu untuk menjadi model atau teladan dalam berprilaku sesuai dengan isi kisah-kisah yang saya sampaikan. Sementara itu, Kompetensi Sosial yang dekat dengan Kompetensi Kepribadian, ditemukan dari data subjek $C$ dan Subjek $D$, mereka merasakan adanya peningkatan kemampuan berkomunikasi pada diri mereka maupun anak didik melalui teknik berkisah.

Berdasarkan hasil penelitian di atas, peneliti mengungkap aspek lain dalam penelitian ini melalui metode penelitian kualitatif, yaitu mengungkap kompetensi guru TK/RA melalui pelatihan berkisah khususnya pada Kompetensi Nilai Keislaman, Meningkatkan Pemahaman Guru pada Anak, dan Kompetensi Moral (tentang nilai-nilai baik dan buruk dalam kehidupan). Penelitian yang relevan di atas dapat memberikan wawasan yang berhubungan dengan kompetensi yang dimiliki guru.

Peran Guru Pendidikan Anak Usia Dini dalam inti pendidikan terjadi dalam prosesnya, yakni situasi dimana terjadi dialog antara peserta didik dengan pendidik yang memungkinkan peserta 
didik tumbuh kearah yang dikehendaki oleh pendidik agar selaras dengan nilainilai yang dijunjung tinggi oleh masyarakat yang berkaitan dengan pendidikan karakter. Berkaitan dengan hal itu, Lubis, Layla Takhfa, et al. (2019) juga menjelaskan bahwa Pendidikan karakter bisa dimulai dengan menanamkan pentingnya ibadah keislaman dilaksanakan sejak dini pada usia anak dan remaja. Jadi, karakter anak yang sehat mental secara utuh bisa dibentuk melalui pemeliharaan ibadah keislaman agar mengembangkan potensi anak sebagai generasi penerus bangsa bagi lingkungan sekitarnya. Melalui teknik berkisah dengan tema keislaman dipandang mampu meningkatkan motivasi anak untuk beribadah berdasarkan nilai keislaman. Dengan pembentukan ibadah keislaman tersebut, karakter anak dari aspek moral, khususnya kepribadian dan emosinal anak akan terbentuk sejak usia dini. Hal tersebut tercapai apabila pendidik atau guru berhasil memberikan pendekatan pembelajaran dan permainan yang tepat kepada anak, misalnya melalui metode berkisah.

Menurut Hymes et al (Allen, 1999: 59) pendidik yang baik untuk anak usia dini adalah memiliki beberapa sifat dan ciri khas, misalnya kepekaan, kemampuan beradaptas, kehangatan hati, jujur, ketulusan hati, bersahaja, kemampuan menghibur, menerima perbedaan individu, mendukung pertumbuhan fisik yang sehat, ketegaran dalam hidup, memiliki sikap simpati dan empatik, penerimaan diri yang baik, emosi yang stabil, percaya diri, dan dapat belajar dari pengalaman.

Selanjutnya dipaparkan secara terperinci peran guru anak usia dini, diantaranya:

a. Peran guru dalam berinteraksi

Guru anak usia dini akan sering berinteraksi dengan anak dalam berbagai bentuk perhatian, baik lisan maupun perbuatan. Guru harus berinisiatif memvariasikan interaksi lisan, seperti dalam memberikan perintah dan bercakap-cakap dengan anak.

b. Peran guru dalam pengasuhan

Pendidik anak usia dini menganjurkan untuk mengasuh dengan sentuhan dan kasih sayang. Pengasuhan saling memengaruhi seperti pelukan, getaran, cara menggendong adalah kebutuhan perkembangan psikologis dan fisik anak.

c. Peran guru dalam mengatur tekanan/ stress

Guru membantu anak untuk belajar mengatur tekanan akan menciptakan permainan dan mempelajari lingkungan yang aman pengelolaan tekanan dan dapat mengatasi kemampuan membantu perkembangan.

d. Peran guru dalam memfasilitasi

Anak-anak membutuhkan kesempatan untuk bermain imajinatif, mengekspresikan diri, menemukan masalah, menyelidiki jalan alternatif dan menemukan penemuan baru untuk mempertinggi perkembangan kreativitas.

e. Peran guru dalam perencanaan

Peran guru perlu merencanakan kebutuhan anak-anak untuk aktivitas mereka, perhatian, stimulasi dan kesuksesan melalui keseimbangan di dalam kelas dan melalui implementasi desain kegiatan yang terencana.

f. Peran guru dalam menangani masalah

Peran guru yang mengetahui kebutuhan individual anak-anak, ketertarikan anak-anak, rasa takut, dan frustasi dan yang memiliki pertimbangan keputusan yang bagus tentang kejadiankejadian di dalam kelas dapat memperkirakan situasi masalah secara efektif.

g. Peran guru dalam pembelajaran

Guru yang melaksanakan reflektif menggambarkan mengajar sebagai suatu perjalanan yang meningkatkan pengertian diri, sementara itu juga meningkatkan sensitivitas dan pengetahuan terbaik anak tentang bagaimana memfasilitasi belajar.

h. Peran guru dalam bimbingan dan pemeliharaan 
Bimbingan adalah proses bantuan yang diberikan oleh guru atau petugas lainnya kepada anak didik dalam rangka memperhatikan kemungkinan adanya hambatan atau kesulitan yang dihadapi anak didik dalam rangka mencapai perkembangan yang optimal. Sedangkan pemeliharaan adalah suatu kegiatan yang dilakukan dengan sadar untuk menstimulus pertumbuhan fisik dan perkembangan mental anak dengan cara tertentu untuk mencapai hasil tertentu.

Berdasarkan uraian di atas menunjukkan bahwa guru adalah profesi yang sangat urgen dalam kegiatan pendidikan (proses belajar mengajar) yang dituntut terus untuk belajar mengembangkan peran atau kinerjanya serta mampu mengoptimalisasikan potensi peserta didik. Guru bisa menggunakan teknik Berkisah dalam menjalankan profesinya. Peserta didik harus diberikan pelayanan dan fasilitas untuk bereksplorasi di lingkungan sekitarnya agar Kompetensi Pedagogis, Kompetensi Kepribadian, Kompetensi Sosial, dan Kompetensi Profesional semakin meningkat melalui profesi guru Taman Kanak-Kanak. Dengan demikian, seluruh potensi dan kompetensi guru bisa berkembang, bahkan mencakup peningkatan Nilai Moral, Nilai Keislaman, maupun memahami perkembangan Anak, khususnya kemampuan berbahasa anak sebagaimana data yang diperoleh dari penelitian ini.

\section{PENUTUP}

Berdasarkan hasil penelitian, ditemukan bahwa pelatihan berkisah meningkatkan kompetensi guru Taman Kanak-Kanak. Kompetensi yang meningkat mencakup Kompetensi Profesional, Kompetensi Kepribadian, Kompetensi Sosial, dan Kompetensi Pedagogis. Peningkatan kompetensi khusus lainnya yang diperoleh guru setelah mengikuti pelatihan teknik berkisah adalah peningkatan Kompetensi Moral dan semakin peka untuk memahami Tahap Perkembangan Anak, khususnya Perkembangan Bahasa Anak. Selain itu, hasil penelitian menunjukkan adanya peningkatan Kompetensi Keislaman pada guru dan anak didik dengan cara guru mengangkat atau memilih kisah-kisah nyata nabi dan rasul dalam memberikan teknik berkisah kepada siswa atau peserta didik anak usia dini.

Sementara itu, hasil penelitian ini memiliki saran-saran terhadap dua dimensi masyarakat. Pertama, kepada guru Taman Kanak-Kanak (TK), dan kedua, kepada akademisi dan peneliti. Pertama, guru TK agar mempelajari dan meningkatkan penggunaan teknik berkisah dalam pembelajaran di kelaskelas pembelajaran. Dengan teknik berkisah, potensi anak akan meningkat sesuai keunikan peseta didik sekaligus mengembangkan kompetensi guru dalam proses belajar mengajar. Kedua, kepada akademisi dan peneliti lain agar dapat mengulas penelitian-penelitian terhadap tentang teknik berkisah atau bercerita (story telling) sehingga dapat menjelaskan referensi ilmiah yang menggambarkan peningkatan potensi lainnya dalam diri guru maupun anak didik. Berkaitan dengan penelitian ini, peneliti lain hendaknya mengembangkan metodemetode penelitian yang lebih sempurna dan komperehensif dalam mensimulasi efektivitas teknik berkisah terhadap peningkatan kompetensi, motivasi, maupun potensi lainnya dalam diri guru sebagai pendidik, khususnya studi dan riset dalam pendidikan anak usia dini.[]

\section{DAFTAR RUJUKAN}

Ahmadi, A. A., Supriyono, W. Psikologi Belajar. Jakarta: Rhineka Cipta. 1991. Amalia, Taranindya Zulhi. "Bercerita Sebagai Metode Mengajar Bagi Guru Raudlatul Athfal Dalam Mengembangkan Kemampuan Dasar Bahasa Anak Usia Dini di Desa Ngembalrejo Bae, Kudus." ThufuLA: Jurnal Inovasi Pendidikan Guru 
Raudhatul Athfal 3.2 (2015): 334353.

Andi Yudha, Asfandiyar. Cara Pintar Mendongeng. Bandung: Mizan Budaya Kreativa. 2007.

Atkinson, R. L \& Atkinson, C. A. tt. Pengantar Psikologi Penerjemah: Widjaja Kusuma. Judul Asli "Introduction to Psychology". Batam: Interakasara.

Azis, Abdul dan Abdul Majid. Mendidik dengan Cerita. Bandung: PT Remaja Rosda Karya. 2008.

Azwar, Saifuddin. Metode Penelitian. Yogyakarta: Pustaka Pelajar. 1999.

Berry, J. W., Poortinga, Y. H., Segall, M. H., Dasen, P. R. Psikologi Lintas Budaya. Penerjemah: Edy Suhardono. Jakarta: Penerbit PT. Gramedia Percetakan Utama. 1999.

Chaplin, J. P. Kamus Lengkap Psikologi. Penerjemah: Dr. Kartini Kartono. Jakarta: PT. Raja Grafindo Persada. 1999.

Djaali. Psikologi Pendidikan. Jakarta: Bumi Aksara. 2014.

Drever, J. Kamus Psikologi. Penerjemah Nancy Simanjuntak. Jakarta: Bina Aksara. 1988.

Fitroh, Siti Fadjryana, and Evi Dwi Novita Sari. "Dongeng sebagai media penanaman karakter pada anak usia dini." Jurnal PG-PAUD Trunojoyo: Jurnal Pendidikan dan Pembelajaran Anak Usia Dini 2.2 (2015): 95-105.

Hall, S.C dan Lindzey, G. Teori-Teori Sifat dan Behavioristik. Penerjemah Supratiknya, A. Yogyakarta: Penerbit Kanisius. 1993.

Hamalik, Oemar. Proses Belajar Mengajar. Jakarta: Bumi Aksara. 2003.

Hijriati. Analisis Kompetensi Guru Paud Dalam Pelaksanaan Pembelajaran Anak Usia Dini di TK IT Salman AlFarisi 1 Yogyakarta. (Magister dissertation, UIN Sunan Kalijaga). 2016.

Larkin, Chuck. What is Storytelling (http://www.eldrbarry.net/roos/st_ is.htm). Accessed on 12-08-2017 (22:15).
Latif, Muhammad Abdul. "The miracle of story telling." Jakarta: Zikrul Hakim (2012).

Leavitt, H. J. Psikologi Manajemen. Penerjemah Dra.Muslichah Zarkasih. Jakarta: Erlangga. 1997.

Leicester, Mal. Early years stories for the foundation stage: ideas and inspiration for active learning. Routledge, 2006.

Lubis, Layla Takhfa, et al. "Peningkatan Kesehatan Mental Anak dan Remaja Melalui Ibadah Keislaman." AlHikmah: Jurnal Agama dan Ilmu Pengetahuan 16.2 (2019): 120-129.

Miles, M.M dan Huberman, A.M. Analisis Data Kualitatif. (Penterjemah: Rohidi.Tj.R) Jakarta: Penerbit Universitas Indonesia. 1992.

Moeslichatoen. Metode Pengajaran di Taman Kanak-kanak. Jakarta: PT Rineka Cipta. 2004.

Moleong, L.J. Metodologi Penelitian Kualitatif. Bandung: Penerbit PT. Remaja Rosdakarya. 2001.

Nurbiana, Dhieni, et al. Metode Pengembangan Bahasa. Jakarta: Universitas Terbuka. 2005.

Poerwandari, E. K. Pendekatan Kualitatif Dalam Penelitian Psikologi. Jakarta: Fakultas Psikologi Universitas Indonesia. 1998.

Pusat Pembinaan dan Pengembangan Bahasa. Kamus Besar Bahasa Indonesia. Edisi Kedua. Jakarta: Balai Pustaka. 1996.

Riyadh, Sa'ad. Melatih Otak dan Komunikasi Anak, Meningkatkan Kecerdasan dan Kemampuan Anak Lewat Cerita. Jakarta: Akbar Media. 2011.

Rohayu, Aprianti Yopita. Menumbuhkan Kepercayaan Diri Melalui Bercerita. Jakarta: Indeks. 2013.

Sardiman A.M. Interaksi \& Motivasi Belajar Mengajar. Jakarta: PT Raja Grafindo Persada. 2007.

Schultz, D. Psikologi Pertumbuhan. Penterjemah: Yustinus. Jogyakarta: Percetakan Kanisius. 1993. 
Slavin, Robert. Psikologi Pendidikan. Jakarta: Rineka Cipta. 2011.

Sonawat, Reeta, and Jasmine Maria Francis. "Language development for preschool children." Mumbai: MultiTech Publishing co (2007).

Suyatinah. Psikologi Pendidikan. Yogyakarta: FIP UNY. 2000.

Syah, Muhibbin. Psikologi Pendidikan dengan Pendekatan Baru. Bandung: Remaja Rosda Karya. 2010.

Uno, Hamzah B. Teori Motivasi \& Pengukurannya Analisis di Bidang Pendidikan. Jakarta: Bumi Aksara. 2008. 